\title{
Increased risk of lung cancer among male professional drivers in urban but not rural areas of Sweden
}

\author{
Robert Jakobsson, Per Gustavsson, Ingvar Lundberg
}

\begin{abstract}
Objectives-To study the risk of lung cancer in different subgroups of professional drivers in urban and rural areas of Sweden.

Methods-Information on occupation and geographical region was obtained from the Swedish census of 1970 and data on the incidence of lung cancer between 1971 and 1984 from the National Swedish Cancer Registry. Professional drivers were separated into bus, taxi, and long and short distance lorry drivers. Comparisons of cumulative incidence of lung cancer were made between each particular group of drivers and gainfully employed men in the same region.

Results-Taxi drivers, and long and short distance lorry drivers in Stockholm County showed increased relative risks (RRs) of lung cancer with the highest risk among the short distance lorry drivers (RR 2.0, 95\% confidence interval (95\% CI) $1 \cdot 5$ to $2 \cdot 6$ ). These categories of drivers also showed increased risks in the other two large conurbations in Sweden. In the rest of the country (mainly rural areas) there were no increased RRs for any category of driver. The RR for bus drivers was not increased in any region. After adjustment for assumed differences in smoking habits the RRs remained significantly increased for lorry drivers in Stockholm but not for other groups of drivers in other areas. However, the RRs remained numerically higher in large conurbations than in rural regions for all groups of drivers.
\end{abstract}

Conclusions-These findings suggest that some factors present in the urban environment play a substantial part in the excess of lung cancer among short distance lorry drivers in urban areas of Sweden. Exposure to motor exhaust fumes may have contributed to this excess.

Occupational Health, North-Western Health Board, Karolinska Hospital, S 17176 Stockholm, Sweden R Jakobsson P Gustavsson I Lundberg

Correspondence to: Dr Robert Jakobsson Department of Occupational Health, Karolinska Hospital, S-171 76 Stockholm, Sweden.

Accepted 8 October 1996 way workers in the United States ${ }^{12}{ }^{13}$ and of Swedish bus garage workers ${ }^{14}$ and dock workers, ${ }^{15}$ indicate that high and prolonged exposure to diesel exhaust is associated with an increased risk of lung cancer. The International Agency for Research on Cancer (IARC) concluded that diesel engine exhaust is probably carcinogenic and petrol engine exhaust is possibly carcinogenic to humans. ${ }^{16}$

One reason for the contradictory results between different studies may be that the type of drivers and the environment in which the work is performed have not been classified sufficiently. Long distance lorry drivers in the United States were exposed to a mean concentration of elemental carbon that was slightly higher than roadside concentrations, but the exposure of forklift truck drivers and dock workers was considerably higher. ${ }^{17}$ City bus drivers in Paris and Bordeaux were exposed to exhaust concentrations close to those prevalent at street level in the more polluted parts of the cities. ${ }^{18}$ These data do not allow general conclusions to be drawn on exposures of different types of drivers.

An analysis of the Swedish Cancer Environment Register for the period 1961-73 showed that male long distance lorry drivers in Sweden, when compared with gainfully employed men in Sweden showed a standardised mortality ratio (SMR) for lung cancer of 1.3 (95\% confidence interval $(95 \% \mathrm{CI}) 1 \cdot 1$ to 1.6) whereas male long distance lorry drivers resident in Stockholm, when compared with gainfully employed men in Stockholm, had an SMR of $1.6(95 \%$ CI $1 \cdot 2$ to $2 \cdot 3) .{ }^{19}$ In the same register a significantly increased risk of lung cancer was found among long distance lorry drivers but not among tanker drivers.

Furthermore, the Swedish Cancer Environment Register for the period 1971-84 showed that although drivers in Sweden, when compared with gainfully employed men in Sweden, had an SMR for lung cancer of 1.2 $(95 \% \text { CI } 1.2 \text { to } 1 \cdot 3)^{20}$ male drivers in Stockholm, when compared with gainfully employed men in Stockholm, had an SMR of $1.6(95 \%$ CI 1.4 to 1.8$) .^{21}$

Thus, epidemiological evidence indicates that professional drivers have an increased risk of lung cancer, although not much is known about the risks among different types of drivers.

The aim of this investigation was to examine the risk of lung cancer in different subgroups of professional drivers in urban and rural areas of Sweden. Data on smoking from previous surveys were used to evaluate the possible impact from smoking. 
Table 1 Number of drivers and cases of lung cancer in the study

\begin{tabular}{|c|c|c|c|c|c|}
\hline \multirow[b]{2}{*}{ Driver group } & \multicolumn{5}{|l|}{ Region } \\
\hline & $\begin{array}{l}\text { Stockholm } \\
\text { County }\end{array}$ & $\begin{array}{l}\text { Gothenburg/ } \\
\text { Bohus } \\
\text { County }\end{array}$ & $\begin{array}{l}\text { Malmohus } \\
\text { County }\end{array}$ & $\begin{array}{l}\text { Counties in } \\
\text { the rest of } \\
\text { Sweden }\end{array}$ & $\begin{array}{l}\text { Sweden, } \\
\text { total }\end{array}$ \\
\hline $\begin{array}{l}\text { Bus drivers } \\
\text { Taxi drivers } \\
\text { Long distance }\end{array}$ & $\begin{array}{l}2359(14) \\
3120(42)\end{array}$ & $\begin{array}{c}992(7) \\
1277(14)\end{array}$ & $\begin{array}{l}715(1) \\
844(14)\end{array}$ & $\begin{array}{l}5380(30) \\
5096(34)\end{array}$ & $\begin{array}{c}9446(52) \\
10337(104)\end{array}$ \\
\hline $\begin{array}{l}\text { lorry drivers } \\
\text { Short distance }\end{array}$ & 7773 (76) & $4367(35)$ & $4339(38)$ & $37513(155)$ & $53992(304)$ \\
\hline lorry drivers & $4118(50)$ & $2148(15)$ & $2513(19)$ & $13884(60)$ & $22663(144)$ \\
\hline
\end{tabular}

\section{Material and methods}

The study population included all gainfully employed Swedish men aged 20 to 64 in 1970. The professional drivers $(n=96438)$ were separated into four categories: bus, taxi, and long and short distance lorry drivers by the occupational code (classified according to the Swedish standard classification of occupations (NYK)) combined with the industry code (according to the Swedish standard industrial classification of economic activities (SNI) table 1). Short distance lorry drivers (including van drivers) mainly perform deliveries within the region. Long distance lorry drivers perform mainly intercity and international deliveries.

Incident cases of cancer for the period 1971-84 have been identified from the National Swedish Cancer Registry and were linked to the data on occupation and residency obtained from the census through the unique 10 digit identification number assigned to every Swedish citizen. This register is known as the Swedish Cancer Environment Registry. Incident cases of lung cancer (ICD-7 code 162) were identified from this register.

The expected number of lung cancers was calculated by the following procedure. The number of people in each category of drivers in 1970 was multiplied by the cumulative lung cancer rate 1971-84 among men who were gainfully employed in 1970 . Effects due to differences in age and geographical regions (county) were accounted for by stratification (five-year age groups were used).

An internally standardised relative risk (RR) was calculated by dividing the observed by the expected numbers of cases. This RR is similar to an SMR based on person-years, although differences in mortality between occupational groups could not be accounted for.

95\% Confidence intervals were calculated from the normal distribution when the number of observed cases exceeded 20, and with an exact method based on the Poisson distrib- ution when the observed cases were less than $20 .{ }^{22}$

Smoking habits from two Swedish surveys were used to estimate the influence to tobacco smoking on the risk of lung cancer. The first was a national survey of smoking habits in $1963 .{ }^{23}$ The frequency of smokers among professional drivers in that survey was $59 \%$ compared with a mean of $49 \%$ among men in the general population. The second set of data was derived from three occupational health service surveys among short distance lorry drivers in Stockholm performed in the $1980 \mathrm{~s}$. On average $50 \%$ of the drivers were smokers (occupational health service reports, Arla-GBSemper AB, Stockholm 1985) but the proportion of smokers among the general male population in Stockholm was 34\% in $1983 .{ }^{24}$

The impact of smoking was shown by calculations of adjusted RRs, based on the smoking habits indicated by these two investigations. Calculations were also performed with a higher excess of smokers among the drivers than that indicated by the surveys. The adjustments for smoking were calculated by a method similar to that described earlier for smoking and myocardial infarction. ${ }^{25}$ It was assumed in the calculations that the risk of lung cancer among non-smokers was a 10th that of smokers and half that of ex-smokers. ${ }^{26}$ One third of the non-smokers were assumed to be ex-smokers. A multiplicative interaction between the risk factors was assumed when the risk estimates were adjusted for smoking. ${ }^{22}$

\section{Results}

The RRs for lung cancer (without adjustment for smoking) differed considerably between the categories of drivers and also between the geographical regions (table 2). The $R R$ was notably increased for short distance lorry drivers in Stockholm county. In the counties without large cities (all counties except Stockholm, Gothenburg/Bohus, and

Table 2 Relative risks (95\% CIs) of lung cancer among male Swedish professional drivers, 1971-84

\begin{tabular}{|c|c|c|c|c|c|}
\hline \multirow[b]{2}{*}{ Driver group } & \multicolumn{5}{|l|}{ Region } \\
\hline & $\begin{array}{l}\text { Stockholm } \\
\text { County }\end{array}$ & $\begin{array}{l}\text { Gothenburg/ } \\
\text { Bohus } \\
\text { County }\end{array}$ & $\begin{array}{l}\text { Malmohus } \\
\text { County }\end{array}$ & $\begin{array}{l}\text { Counties in } \\
\text { the rest of } \\
\text { Sweden }\end{array}$ & $\begin{array}{l}\text { Sweden, } \\
\text { total }\end{array}$ \\
\hline Bus drivers & $0.8(0.4-1.3)$ & $1.0(0.4-2.0)$ & $-\star \star$ & $1 \cdot 1(0 \cdot 7-1 \cdot 6)$ & $0.9(0.7-1.2)$ \\
\hline $\begin{array}{l}\text { Taxi drivers } \\
\text { Long distance }\end{array}$ & $1.5(1 \cdot 1-2 \cdot 1)$ & $1 \cdot 4(0 \cdot 8-2 \cdot 3)$ & $1 \cdot 8(1.0-3 \cdot 0)$ & $1.0(0.7-1.4)$ & $1.4(1.1-1.7)$ \\
\hline $\begin{array}{l}\text { lorry drivers } \\
\text { Short distance }\end{array}$ & $1.6(1.3-2 \cdot 0)$ & $1.4(1.0-2 \cdot 0)$ & $1.3(0.9-1.7)$ & $1 \cdot 1(0.9-1 \cdot 3)$ & $1 \cdot 2(1 \cdot 1-1 \cdot 4)$ \\
\hline lorry drivers & $2.0(1.5-2.6)$ & $1 \cdot 3(0 \cdot 7-2 \cdot 2)$ & $1 \cdot 1(0 \cdot 7-1 \cdot 7)$ & $1 \cdot 1(0.9-1 \cdot 4)$ & $1.4(1.2-1 \cdot 6)$ \\
\hline
\end{tabular}


Table 3 Relative risks (95\% CIs) of lung cancer among male Swedish professional drivers, 1971-84, adjusted for tobacco smoking ${ }^{\star}$

\begin{tabular}{llllll}
\hline & Region & & & \\
\cline { 2 - 6 } & $\begin{array}{l}\text { Stockholm } \\
\text { County }\end{array}$ & $\begin{array}{l}\text { Gothenburg/ } \\
\text { Bohus } \\
\text { County }\end{array}$ & $\begin{array}{l}\text { Malmohus } \\
\text { County }\end{array}$ & $\begin{array}{l}\text { Counties in } \\
\text { the rest of } \\
\text { Sweden }\end{array}$ & $\begin{array}{l}\text { Sweden, } \\
\text { total }\end{array}$ \\
\hline $\begin{array}{l}\text { Taxi drivers } \\
\text { Long distance }\end{array}$ & $1.3(1.0-1.8)$ & $1.2(0.9-1 \cdot 7)$ & $1.5(0.8-2.6)$ & $0.9(0.6-1 \cdot 2)$ & $1.2(1.0-1 \cdot 4)$ \\
$\begin{array}{l}\text { lorry drivers } \\
\text { Short distance } \\
\text { lorry drivers }\end{array}$ & $1.4(1.1-1.8)$ & $1.2(0.9-1 \cdot 7)$ & $1 \cdot 1(0.8-1.5)$ & $0.9(0.8-1 \cdot 1)$ & $1.1(0.9-1 \cdot 2)$ \\
\hline
\end{tabular}

^Smoking habits from 1963 national survey; $59 \%$ were smokers among the professional drivers, $49 \%$ among the reference population.

Malmöhus) there were no increased RRs for any category of driver. Also there were no increased risks for bus drivers in any of the geographical areas. For the other categories of drivers increased risks were found in the three urban regions (the Counties of Stockholm, Gothenburg/Bohus, and Malmöhus), and the RRs tended to be higher in Stockholm than in Gothenburg/Bohus and Malmöhus Counties.

Table 3 shows the risks of lung cancer adjusted for different smoking habits. Bus drivers were not included in this calculation as they did not show an increased risk in any of the regions.

The risk of lung cancer in all categories of driver decreased after adjustment for assumed differences in smoking habits. With the data from the 1963 smoking survey (indicating a slightly higher prevalence among the drivers compared with other gainfully employed men) a significantly increased risk remained for taxi drivers, and long and short distance lorry drivers in Stockholm County. With the data from the occupational health service survey from Stockholm in the 1980s (indicating a high overrepresentation of smokers among the drivers compared with the general male population in Stockholm at that time) there was still an increased $R R$ for long and short distance lorry drivers, but the $R R$ for taxi drivers was no longer significant. If an even higher proportion $(60 \%)$ of smokers was assumed among the drivers the risk remained significantly increased among the short distance lorry drivers only.

\section{Discussion}

The study shows large differences in risk of lung cancer between bus, taxi, and long and

Table 4 Relative risks (95\% CIs) of lung cancer among male professional drivers in Stockholm County, 1971-84, adjusted for different distribution of tobacco smoking

\begin{tabular}{llll}
\hline & $\begin{array}{l}1963 \text { National } \\
\text { survey of } \\
\text { smoking habits }\end{array}$ & $\begin{array}{l}\text { Occupational } \\
\text { health service } \\
\text { investigationt }\end{array}$ & $\begin{array}{l}\text { Simulated } \\
\text { smoking } \\
\text { distributionf }\end{array}$ \\
\hline $\begin{array}{l}\text { Taxi drivers } \\
\text { Long distance }\end{array}$ & $1 \cdot 3(1 \cdot 0-1 \cdot 8)$ & $1 \cdot 2(0 \cdot 8-1 \cdot 6)$ & $1 \cdot 0(0 \cdot 7-1 \cdot 4)$ \\
$\begin{array}{l}\text { lorry drivers } \\
\text { Short distance }\end{array}$ & $1.4(1 \cdot 1-1 \cdot 8)$ & $1 \cdot 2(1 \cdot 0-1 \cdot 5)$ & $1 \cdot 1(0 \cdot 9-1 \cdot 3)$ \\
lorry drivers & $1 \cdot 7(1 \cdot 3-2 \cdot 3)$ & $1 \cdot 5(1 \cdot 1-2 \cdot 0)$ & $1 \cdot 3(1 \cdot 0-1 \cdot 7)$ \\
\hline
\end{tabular}

*Smoking habits from the 1963 national survey; $59 \%$ were smokers among the professiona drivers, $49 \%$ among the reference population

tSmoking habits from the occupational health service surveys in Stockholm during the 1980s of short distance lorry drivers; $50 \%$ were smokers among the professional drivers, $34 \%$ among the reference population.

reference population. †Simulated,
population. short distance lorry drivers. One interesting result is the striking increase in risk for short distance lorry drivers in Stockholm by contrast with no increase in risk among the bus drivers. There was an increased risk of lung cancer in all groups of professional drivers in Stockholm County except among the bus drivers. A similar pattern appeared in the other urban regions with the exception of short distance lorry drivers in Malmöhus County. In the rest of Sweden, consisting mainly of rural areas with smaller cities, no excess risk of lung cancer was found in any subgroup of drivers.

Some methodological aspects of the study are noteworthy.

The separation of lorry drivers into short and long distance drivers was based only on information about which branch of the industry the driver belonged to, and some misclassification between these categories is probable. Thus, the risk would tend to average out between these two categories of drivers.

Self reported data on occupation during one week in 1970 were used, and some of the drivers might have had their job only for a short time. This would tend to lower the risk of lung cancer due to occupational exposures. On the other hand overall mortality, and also mortality from lung cancer, may be substantially higher among short term workers than the general population for reasons unrelated to occupational exposures. ${ }^{27}$

The cancer cases were identified from the Swedish Cancer Registry. This register has a high accuracy and completeness. ${ }^{28}$ Any misclassification of the outcome would be independent of exposure and thus tend to bias the $R R$ towards unity.

The calculated RRs were approximate as person-years could not be calculated in the absence of data on mortality. An investigation of the mortality from all causes during 1971-80 for all male Swedish road transportation workers active in 1970 showed an SMR of 97. ${ }^{29}$ This indicates that the bias from the approximation in the RRs would be small.

What are the most likely explanations to our findings? Smoking is a well known and strong risk factor for lung cancer. Engine exhausts and pollution in ambient air in urban areas are other possible causes. Several studies during the past decade have indicated a relation between dietary factors and the risk of lung cancer. Foremost, $\beta$-carotene seems to have a protective effect against lung cancer ${ }^{30}$ but this effect has been questioned recently. ${ }^{31}$ 
As already stated there probably was a difference in smoking habits between the professional drivers in our study and the general population. Direct information on the smoking habits of the driver groups in our study is missing. We used data from two investigations and a simulated smoking distribution when we calculated the risk of lung cancer adjusted for smoking. The first investigation of smoking habits was of all professional drivers in Sweden in 1963 and the second was of short distance lorry drivers in Stockholm in the 1980s. There probably is a difference in the proportion of smokers among the subgroups of drivers. Bus drivers probably smoke less than short distance lorry drivers as it has been forbidden to smoke on Swedish local buses. The taxi drivers probably also smoke less than the short distance lorry drivers because the customers may disapprove of smoking. On the other hand, during earlier decades taxi drivers were probably exposed to environmental tobacco smoke from customers who smoked. Also, lorry drivers may be exposed to considerable amounts of environmental tobacco smoke, both from their own smoking and from assistants in the cabin. However, a recent study of concentrations of polycyclic aromatic hydrocarbons and dust in the breathing zone of lorry drivers in Geneva showed no increased concentrations among drivers who were smokers. ${ }^{32}$ This indicates that the ventilation of the lorry cabins in modern lorries is sufficient to remove tobacco smoke relatively quickly.

We have provided RRs adjusted for a moderate excess of smokers among the drivers and a more pronounced difference in smoking habits between the drivers in Stockholm county and the reference population. Probably the smoking habits of the short distance lorry drivers were more different from the general population than the smoking habits of the taxi drivers. Under these assumptions the excess risk of lung cancer remained in both these groups of drivers after adjustment for smoking habits.

The exposure to engine exhaust fumes and ambient air pollution among different kinds of drivers is insufficiently investigated. The exposure to exhaust fumes in central Paris was two to three times higher in motor cars than for other means of transportation, including walking. ${ }^{33}$ In Geneva the exposures to motor exhaust fumes were higher for short distance lorry drivers than for long distance lorry drivers. ${ }^{32}$ The available exposure data are insufficient to find if the difference in risk of lung cancer between the groups of drivers in our study may be attributed to different levels of exposure to motor exhaust fumes.

In a Swedish case-control study of lung cancer a very high $R R$ was found among former professional drivers over 70 years of age who smoked more than 20 cigarettes a day compared with age and smoking matched nondrivers. The findings were interpreted as a synergistic effect between smoking and occupation. ${ }^{4}$ A case-control study nested within a cohort of Swedish dock workers found a notably higher $R R$ of lung cancer among smokers with a high exposure to diesel exhaust than among smokers with low exposure to diesel exhaust. The findings were interpreted as being due to an interaction between smoking and diesel exhaust. ${ }^{15}$

A recently published study of lorry drivers and taxi drivers in Iceland confirms the differences in the risk of lung cancer between subgroups of drivers. A significantly increased risk of lung cancer was found among lorry drivers but not among taxi drivers. Although the lorry drivers smoked more than the reference population the increased risk could not be explained by tobacco smoking only. ${ }^{34}$ The result from our study is in keeping with these findings and suggests an interaction between exposure to engine exhaust fumes and smoking.

Our finding of no increased risk of lung cancer among bus drivers is also in keeping with previous studies. ${ }^{35} 36$

In conclusion, by dividing professional drivers in the Swedish census of 1970 into subgroups of drivers and geographical regions a pattern of different risk of lung cancer was shown. A substantially increased risk of lung cancer was found among short distance lorry drivers in Stockholm County. An increased risk was also found among taxi drivers and long distance lorry drivers in Stockholm. No excess risk was found for bus drivers in any region. Outside the large conurbations there was no excess of lung cancer in any subgroup of drivers. Calculations of the possible influence of smoking indicate that it is unlikely that the excess risk among drivers in Stockholm is entirely caused by increased smoking habits.

Exposure to engine exhaust fumes from ambient air or their own vehicle may have played a part in the observed excess risk of lung cancer among the drivers, particularly in Stockholm County where the traffic is more dense than in other parts of Sweden. More research is needed to clarify the role of these factors in the explanation of the excess risk of lung cancer among the drivers.

We thank $\mathrm{Mr} \mathrm{H}$ Kiviranta for computer analyses. This study is a part of a programme directed towards identincation and prevention of work related hazards among professional drivers in Stockholm County. The programme is under the supervision of a group with representatives from trade unions, employers, occupational health service of the Swedish transport occupational health service of the Swedish transport trade, and the factory inspectorate. We thank the representatives of these organisations for support of the programme. The study was
financially supported by the Stockholm County Council.

1 Hansen ES. A follow-up study on the mortality of truck drivers. $A m$ F Ind Med 1993;23:81 1-21.

inized truck drivers. $f$ Occup Med $1978 ; 20: 677$. Mortality in

3 Steenland NK, Silverman DT, Hornung RW. Case-control study of lung cancer and truck driving in the teamsters study of lung cancer and truck driving in
union. Am $\mathcal{F}$ Public Health 1990;80:670-4.

4 Damber L, Larsson LG. Professional driving, smoking, and lung cancer: a case referent study. $B r \mathcal{F}$ Ind Med $1985 ; 42: 246-52$

5 Benhamou S, Benhamou E, Flamant R. Occupational risk factors of lung cancer in a French case-control study. $\mathrm{Br} \mathcal{F}$ Ind Med 1988;45:231-3.

6 Gubéran E, Usel M, Raymond L, Bolay J, Fioretta G, Puissant J. Increased risk for lung cancer and for cancer of the gastrointestinal tract among Geneva professional drivers. Br F Ind Med 1992;49:337-44.

7 Balarajan R, McDowall ME. Professional drivers in London: a mortality study. $\mathrm{Br}$ F Ind Med 1988;45:483-6.

8 Hayes RB, Thomas T, Silverman DT, Vineis P, Blot WJ Mason TJ, et al. Lung cancer in motor exhaust-related occupations. Am F Ind Med 1989;16:685-95. 
9 Raffle PAB. The health of the worker. Br $\mathcal{F}$ Ind Med 1957; 14:73-80

10 Waller RE. Trends in lung cancer in London in relation to exposure to diesel fumes. In: Pepelko WE, Danner RM, Clark NA, eds. Health effects of diesel engine emissions. Washington: US Environmental Protection Agency, 1980:1085-97.

11 Boffetta P, Harris R, Wynder E. Case-control study on occupational exposure to diesel exhaust and lung cance risk. Am F Ind Med 1990;17:577-91.

12 Garshick E, Schenker M, Munoz A, Segal M, Smith T, Woskie $S$, et al. A case control study of lung cancer and diesel exhaust exposure in railroad workers. $A m$ Rev Respir Dis 1987;135:1242-8.

13 Garshick E, Schenker MB, Munoz A, Segal M, Smith TJ, Woskie SR, et al. A retrospective cohort study of lung Woskie SR, et al. A retrospective cohort study of lung cancer and diesel exhaust exposure

14 Gustavsson P, Plato N, Lidström E-B, Hogstedt C. Lung cancer and exposure to diesel exhaust among bus garag workers. Scand $\mathcal{F}$ Work Environ Health 1990;16:348-54.

15 Emmelin A, Nyström L, Wall S. Diesel exhaust exposure and smoking: a case-referent study of lung cancer among Swedish dock workers. Epidemiology 1993;4:237-44.

16 International Agency for Research on Cancer. Diesel and gasoline engine exhausts and some nitroarenes. IARC monographs on the evaluation of the carcinogenic risk of chemicals to humans. Lyon: IARC, 1989:46.

17 Zaebst DD, Clapp DE, Blade LM, Marlow DA, Steenland $\mathrm{K}$, Hornung RW, et al. Quantitative determination of trucking industry workers. Exposure to diesel exhaust trucking industry workers. Exposure to dies.

18 Limasset CL, Diebold F, Hubert G. Assessment of bus drivers' exposure to the pollutants of urban traffic. Sci Total vers' exposure to the polluta

19 Ahlberg J, Ahlbom A, Lipping H, Norell S, Österblom L. Cancer among professional drivers' a register study. Läkartidningen 1981;78:1545-6. (In Swedish.)

20 Ahlbom A, Gerhardsson M, Hogstedt C, Lundberg I, Plato N, Steineck G, Tornling G. Occupation and cancer. Report from Institute of Environmental Medicine. Stockholm Karolinska Institute, 1990. (In Swedish.)

21 Department of Occupational Health, Karolinska Hospital. Work Environment Report. Stockholm: Department of Occupational Health, Karolinska Hospital, 1991. (In Swedish.)
22 Ahlbom A. Biostatistics for epidemiologists. Boca Raton, FL: Lewis, 1990.

23 Statistics Sweden. Smoking habits in Sweden. A mail surveyspring 1963. Stockholm: Statistics Sweden, 1965. (In Swedish.)

24 National Board of Health and Welfare. Smoking habits in Sweden. Stockholm: National Board of Health and Welfare, 1986

25 Gustavsson P, Alfredsson L, Brunnberg H, Hammar N, Jakobsson R, Reuterwall C, Östlin P. Myocardial infarction among male bus, taxi, and lorry drivers in middle Sweden Occup Environ Med 1996;53 235-40.

26 Pike MC, Henderson BE. Epidemiology of polycyclic hydrocarbons: quantifying the cancer risk from cigarette smoking and air pollution. In: Gelboin H, Ts'o P. Polycyclic hydrocarbons and cancer. Vol 3. London: Academic cyclic hydrocar

27 Ohlson CG, Hogstedt C. Lung cancer among asbestos cement workers. A Swedish cohort study and a review. $B$ cement workers. A Swedish coh
IInd Med 1985;42:397-402.

28 Mattsson B. Cancer registration in Sweden [thesis] Stockholm: Karolinska Institute, 1984.

29 Occupational mortality in the Nordic Countries 1971-80. Copenhagen: Nordic Statistical Secretariat, 1988.

30 Fontham ETH. Protective dietary factors and lung cancer. Am $\mathcal{f}$ Epidemiol 1990;19(suppl 1):32-42.

31 Ziegler RG, Mayne ST, Swanson CA. Nutrition and lung cancer. Cancer Causes Control 1996;7:157-77.

32 Guillemin $M$, Herrera $H$, Huynh $C$, Droz P-O, Vu Duc T. Occupational exposure of truck drivers to dust and polynuclear aromatic hydrocarbons: a pilot study in polynuclear aromatic hydrocarbons: a pilot study in Geneva, Switzer

33 Dor F, Moullec Y, Festy B. Exposure of city residents to carbon monoxide and monocyclic aromatic hydrocarbons during commuting trips in the Paris Metropolitan area. F Air Waste Manage Assoc 1995;45:103-10.

34 Rafnsson V, Gunnarsdóttir H. Mortality among professional drivers. Scand $f$ Work Environ Health 1992;17: 312-7.

35 Paradis G, Theriault G, Tremblay C. Mortality in a historical cohort of bus drivers. Int 7 Epidemiol 1989;18: 397-402.

36 Michaels D, Zoloth SR. Mortality among urban bus drivers. Int F Epidemiol 1991;20:399-404.

\section{Rejected manuscripts}

From February 1994, authors whose submitted articles are rejected will be advised of the decision and one copy of the article, together with any reviewers' comments, will be returned to them. The fournal will destroy remaining copies of the article but correspondence and reviewers' comments will be kept. 